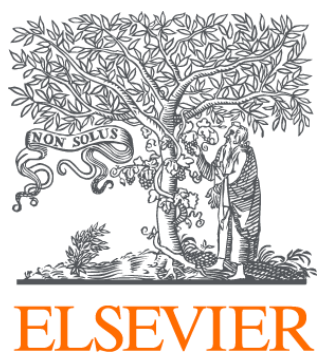

Since January 2020 Elsevier has created a COVID-19 resource centre with free information in English and Mandarin on the novel coronavirus COVID-

19. The COVID-19 resource centre is hosted on Elsevier Connect, the company's public news and information website.

Elsevier hereby grants permission to make all its COVID-19-related research that is available on the COVID-19 resource centre - including this research content - immediately available in PubMed Central and other publicly funded repositories, such as the WHO COVID database with rights for unrestricted research re-use and analyses in any form or by any means with acknowledgement of the original source. These permissions are granted for free by Elsevier for as long as the COVID-19 resource centre remains active. 


\title{
Design of the First Highly Potent and Selective Aminopeptidase N (EC 3.4.11.2) Inhibitor
}

\author{
Huixiong Chen, Bernard P. Roques ${ }^{*}$ \& Marie-Claude Fournié-Zaluski \\ Département de Pharmacochimie Moléculaire et Structurale INSERM U266 - CNRS UMR 8600 \\ UFR des Sciences Pharmaceutiques et Biologiques $\bullet$, avenue de l'Observatoire 75270 PARIS Cedex 06 $\bullet$ FRANCE
}

Received 11 January 1999; accepted 15 April 1999

\begin{abstract}
A series of phosphinic compounds mimicking the transition state of substrates hydrolysed by aminopeptidase N (EC 3.4.11.2) were synthesized. These new compounds have potent inhibitory activities with $\mathrm{Ki}$ values in the nanomolar range. These derivatives behave as the most potent APN inhibitors designed to date. () 1999 Elsevier Science Ltd. All rights reserved.
\end{abstract}

Keywords : Enzyme inhibitors / Phosphinic acids and derivatives / Resolution.

APN, a monomeric or homodimeric type II membrane-bound zinc exopeptidase, is widely distributed in mammalian tissues including the central nervous system and is particularly abundant at the level of the kidney, the intestine and the lung ${ }^{1}$. In vivo, this enzyme is involved in the metabolism of angiotensin III in the brain and peripheral organs ${ }^{2}$, in the degradation of nociceptin ${ }^{3}$ and in the inactivation of enkephalins, in association with neutral endopeptidase NEP ${ }^{4}$. Furthermore, APN has been proved to be identical to a human lymphocyte surface cluster differentiation antigen $\mathrm{CD} 13^{5}$, and to behave as a receptor for coronaviruses TGEV and 229E in pigs and humans ${ }^{6,7}$. APN has been also reported to play an important role in the invasion of metastatic tumors in vitro ${ }^{8.9}$. All these findings make this enzyme an interesting target for possible therapeutic applications, which require the development of potent and selective inhibitors.

APN exhibits a broad specificity for peptides with a $\mathrm{N}$-terminal neutral or basic amino acid such as alanine, arginine or leucine. Sequence comparisons and site-directed mutagenesis experiments ${ }^{10-12}$ have suggested that this enzyme has the same mode of zinc coordination as thermolysin ${ }^{13}$. In APN, the zinc is coordinated by three residues, two histidines found in a consensus sequence ${ }^{383} \mathrm{HEXXH}^{387}$, and a glutamate $\left(\mathrm{E}^{406}\right)$ bound 18 residues $\mathrm{C}$-terminal to the second histidine. The glutamate of the consensus sequence acts as a general base in catalysis. But, until now, little is known about the structure and the mechanism of action of this enzyme.

Natural products such as bestatin ${ }^{14}$, amastatin ${ }^{15}, \mathrm{MA}-387 \mathrm{~A}$ and $\mathrm{B}{ }^{16}$ and actinonin ${ }^{17}$ have been found to act as inhibitors of APN. Bestatin and amastatin have been the most extensively studied. Amastatin

\footnotetext{
* Correspondence. Bernard P. Roques, Tel. (33)-1-43.25.50.45. - Fax. (33)-1-43.26.69.18. - roques@pharmacic.univ-paris5.fr
} 
showed the greatest efficiency on APN with $\mathrm{IC}_{30}$ around $80 \mathrm{nM}$, but this compound presents a poor selectivity versus other aminopeptidases. Synthetic APN inhibitors have been developed from analogues of amino acids including aminohydroxamates ${ }^{18}, B$-aminothiols ${ }^{19}$, aminoboronic acids ${ }^{20}$, aminophosphonic acids ${ }^{21}$ and aminoaldehydes ${ }^{22}$. Among them, only $B$-aminothiols ${ }^{19}$ are both selective and relatively potent inhibitors with $\mathrm{Ki}$ values around $10^{-8} \mathrm{M}$. In order to improve APN inhibition, mercapto analogues of bestatin ${ }^{23}$ or diaminothiols ${ }^{24}$ have been prepared. Unfortunately these compounds did not significantly increase APN recognition. Furthermore, peptide analogues bearing ketomethylene or hydroxyethylene bonds ${ }^{25}$ or $\alpha$-ketoamide groups ${ }^{26}$ were shown to have $\mathrm{IC}_{50} \mathrm{~s}$ in the $10^{-6} \mathrm{M}$ range. Non peptide inhibitors have been also prepared ${ }^{27,28}$ with the aim to obtain compounds with increased stability and better bioavailability. However their $\mathrm{Ki}$ values were found in the $10^{7}-10^{-8}$ molar range and their activities in vivo have not been reported. In order to design potent and selective APN inhibitors, we use the concept of "transition state" analogues capable to interact with the $S_{1}, S_{1}{ }^{\prime}$ and $S_{2}{ }^{\prime}$ subsites of the active site ${ }^{29}$ and endowed with a phosphinic group as zinc ligand. Inhibitors of endopeptidases matrix metalloendopeptidases ${ }^{30}$, containing a phosphinic acid as zinc ligand have been already described, but until now this type of molecules with a free amino group for aminopeptidase inhibition was not reported. In a first time, $\alpha$-aminophosphinic acids bearing a hydrophobic side chain interacting with the $S_{1}$ subsite were synthesized and found to inhibit APN in the $10^{-7}$ molar range. Coupling of these $\alpha$-aminophosphinic acids with an analogue of the dipeptide PhePhe, which has been shown to recognize efficiently the $S_{1}{ }^{\prime}$ and $S_{2}{ }^{\prime}$ subsites of APN ${ }^{31}$, provided new "phosphino"peptides which have the most potent inhibitory activities towards APN described until now.

\section{CHEMISTRY}

The general scheme for the synthesis of inhibitors is reported in Figure 1. The benzyloxycarbonyl $(Z)$ protected phosphinic acids 1 a-f were prepared following previously reported methods ${ }^{32}$ and were
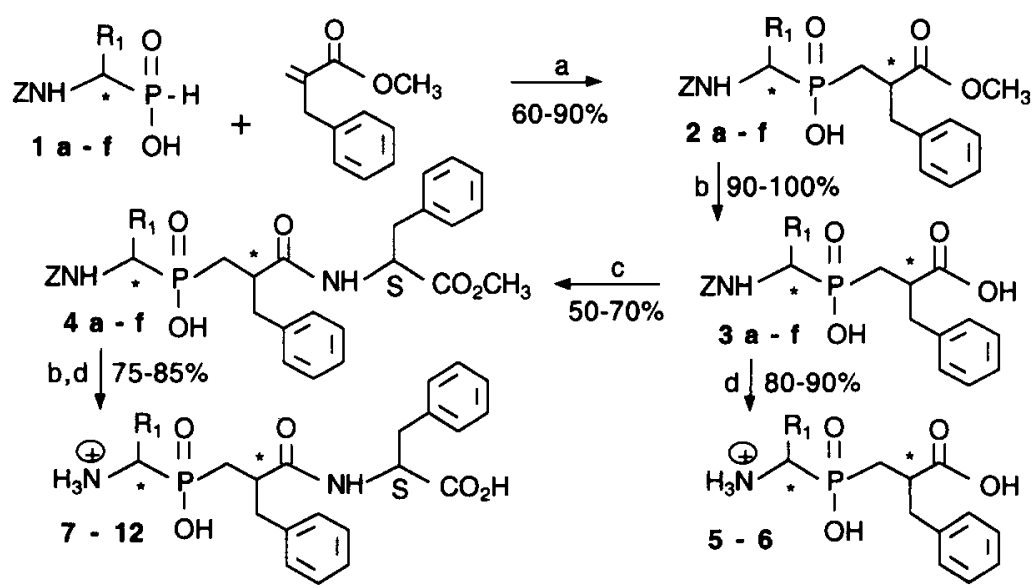

$a, B S A \cdot b, 1 \mathrm{~N} \mathrm{NaOH}$ or $1 \mathrm{~N} \mathrm{LOH} \bullet \mathrm{c}, \mathrm{Phe}-\mathrm{OCH}_{3} / \mathrm{BOP} / \mathrm{DIEA} \cdot \mathrm{d}, \mathrm{BBr}_{3} \bullet *$, mixture of $\mathrm{R}$ and $\mathrm{S}$ isomers

Figure 1. Scheme for the synthesis of the APN inhibitors 
condensed with methyl 2-benzyle acrylate in presence of N,O-bistrimethylsilylacetamide, yielding 2 a-f.

The successive hydrolysis of the methyl ester (compounds 3 ) and cleavage of the $\mathrm{Z}$ protective group gave the dipeptide analogues 5 and 6.

The coupling of 3 a-f with phenylalanine methyl ester led to 4 a-f and a two steps deprotection gave compounds 7 to 12. These latter were obtained as mixtures of four stereoisomers due to the presence of two unresolved asymmetric carbons. Preparative HPLC yielded generally two fractions, each containing two isomers $(\mathrm{A}+\mathrm{B})$ and $(\mathrm{C}+\mathrm{D})$. They were firstly tested on APN without further separation.

\section{RESULTS AND DISCUSSION}

In a first step, the inhibitory activities of various $\alpha$-aminophosphinic acids containing a hydrophobic side chain were measured on pig kidney APN (purchased from Boehringer) and compared with those of the corresponding $B$-aminothiols (Table 1). It is interesting to note that the inhibitory activities of $\alpha$ aminophosphinic acids are very dependent on the nature of the $R_{1}$ side chain, the best results being obtained with compounds containing phenylethyl or ethyl-S-methyl side chains with $\mathrm{Ki}$ values of $1.3 \times 10^{-7} \mathrm{M}$ and $4 \times 10^{-7} \mathrm{M}$ respectively (Table 1 ). Unexpectedly the less active compound contains a methyl side chain mimicking the alanine residue considered as the "model-substrate" of APN. For the corresponding Baminothiols, the inhibitory potencies are almost the same whatever the nature of $R_{1}$, with $K i$ values from 1.1 to $3 \times 10^{-8}$, in agreement with previous results ${ }^{19}$, giving compounds which are 30 to 400 fold most active than the $\alpha$-aminophosphinic acids. However, this ratio is certainly overestimated since the stereodependance of APN towards its inhibitors is very important ${ }^{19}$ and the B-aminothiols were tested as pure stereoisomers while the $\alpha$-aminophosphinic acids were under racemic forms.

Table 1. Inhibitory potencies of analogues of phosphinic acid and B-amino thiols for APN.

\begin{tabular}{|c|c|c|}
\hline & $\underbrace{\mathrm{H}_{2} \mathrm{~N}}_{*} \underset{\mathrm{O}}{\mathrm{O}} \mathrm{O}_{\mathrm{O}}^{\mathrm{O}}$ & $\mathrm{H}_{2} \mathrm{~N} \underbrace{\mathrm{R}_{1}}_{(\mathrm{S})} \mathrm{SH}$ \\
\hline $\mathbf{R}_{1}$ & \multicolumn{2}{|c|}{$A P N^{a}, \operatorname{Ki}(M)^{b}$} \\
\hline $\mathrm{CH}_{3}$ & $8.4 \pm 0.5 \times 10^{-6}$ & $2.8 \pm 0.1 \times 10^{-8}$ \\
\hline $\mathrm{CH}_{2} \mathrm{CH}\left(\mathrm{CH}_{3}\right)_{2}$ & $1.2 \pm 0.1 \times 10^{-6}$ & $2.2 \pm 0.2 \times 10^{-8}$ \\
\hline$\left(\mathrm{CH}_{2}\right)_{2} \mathrm{SCH}_{3}$ & $4.0 \pm 0.5 \times 10^{-7}$ & $1.1 \pm 0.1 \times 10^{8}$ \\
\hline $\mathrm{Ph}$ & $4.8 \pm 0.5 \times 10^{-6}$ & $2.5 \pm 0.2 \times 10^{-8}$ \\
\hline $\mathrm{CH}_{2} \mathrm{Ph}$ & $9.6 \pm 0.2 \times 10^{-7}$ & $3.0 \pm 0.5 \times 10^{-8}$ \\
\hline $\mathrm{CH}_{2} \mathrm{CH}_{2} \mathrm{Ph}$ & $1.3 \pm 0.1 \times 10^{-7}$ & $2.7 \pm 0.7 \times 10^{-8}$ \\
\hline
\end{tabular}

\footnotetext{
aPN activity, from pig kidney, was measured using Ala-p.NA as substrate. ${ }^{\text {b }} \mathrm{Ki}$ values are the mean \pm SEM from three independent experiments performed in triplicate. ${ }^{c}$ analogues of phosphinic acid are racemic mixtures. ${ }^{d} B$-amino thiols are optically pure $S$ isomers.
}

However, these compounds are more efficient than the corresponding aminoacid analogues such as $\alpha$ aminohydroxamates or $\alpha$-aminophosphates (not shown) suggesting that the phosphinic moiety would be an 
interesting alternative to the thiol group for $\mathrm{Zn}$ chelation in the catalytic site of APN.

In a second step, the inhibitory potencies of compounds 5 and 6 which have been designed to interact

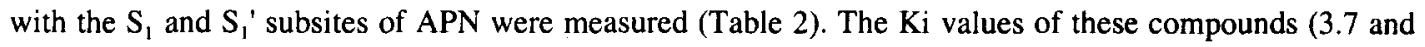
$1.9 \times 10^{-7} \mathrm{M}$ ) were only slightly increased as compared to those of the corresponding $\alpha$-aminophosphinic acids $\left(1.2 \times 10^{-6} \mathrm{M}\right.$ and $\left.9.6 \times 10^{-7} \mathrm{M}\right)$. However, according for the presence of two unresolved asymmetric centers in these compounds, it could be assumed that the occupancy of the $S_{1}$ ' subsite led to a gain in affinity of about one order of magnitude. These data confirms the efficiency of the phosphinic group as zinc ligand for APN inhibition, but also demonstrate the necessity of interacting with the $S_{2}{ }^{\prime}$ subsite of APN for an optimal inhibition of this enzyme.

Table 2. Inhibitory potencies of phosphinic derivatives for APN.

\begin{tabular}{|c|c|c|c|c|c|}
\hline $\mathbf{n}$ & & $\mathbf{x}$ & R1 & $\mathbf{A A}$ & $\operatorname{APN}^{b}\left(\mathrm{Ki}(\mathrm{nM})^{a}\right)$ \\
\hline $5^{\circ}$ & & $\mathrm{NH}_{2}$ & $\mathrm{CH}_{2} \mathrm{CH}\left(\mathrm{CH}_{3}\right)_{2}$ & $\mathrm{OH}$ & $370 \pm 80$ \\
\hline $6^{\circ}$ & & $\mathrm{NH}_{2}$ & $\mathrm{CH}_{2} \mathrm{Ph}$ & $\mathrm{OH}$ & $190 \pm 30$ \\
\hline 7 & $\begin{array}{l}(\mathbf{A}+\mathbf{B}) \\
(\mathbf{C}+\mathbf{D})\end{array}$ & $\mathrm{NH}_{2}$ & $\mathrm{CH}_{3}$ & Phe & $\begin{array}{l}2.2 \pm 0.2 \\
670 \pm 90\end{array}$ \\
\hline 8 & $\begin{array}{l}(A+B) \\
(C+D)\end{array}$ & $\mathrm{NH}_{2}$ & $\mathrm{CH}_{2} \mathrm{CH}\left(\mathrm{CH}_{3}\right)_{2}$ & Phe & $\begin{array}{c}3.2 \pm 0.5 \\
90 \pm 16\end{array}$ \\
\hline 9 & $\begin{array}{l}(A+B) \\
(C+D)\end{array}$ & $\mathrm{NH}_{2}$ & $\mathrm{CH}_{2} \mathrm{CH}_{2} \mathrm{SCH}_{3}$ & Phe & $\begin{array}{l}6.3 \pm 0.3 \\
370 \pm 20\end{array}$ \\
\hline 10 & $\begin{array}{l}(\mathrm{A}+\mathrm{B}) \\
(\mathrm{C}+\mathrm{D})\end{array}$ & $\mathrm{NH}_{2}$ & $\mathrm{Ph}$ & Phe & $\begin{array}{c}3.8 \pm 0.48 \\
320 \pm 10\end{array}$ \\
\hline 11 & $\begin{array}{l}(A+B) \\
(C+D)\end{array}$ & $\mathrm{NH}_{2}$ & $\mathrm{CH}_{2} \mathrm{Ph}$ & Phe & $\begin{array}{l}2.9 \pm 0.8 \\
200 \pm 40\end{array}$ \\
\hline 12 & $\begin{array}{l}(A+B) \\
(C+D)\end{array}$ & $\mathrm{NH}_{2}$ & $\mathrm{CH}_{2} \mathrm{CH}_{2} \mathrm{Ph}$ & Phe & $\begin{array}{l}2.3 \pm 0.4 \\
360 \pm 60\end{array}$ \\
\hline
\end{tabular}

\footnotetext{
${ }^{a} \mathrm{Ki}$ values are the mean \pm SEM from three independent experiments performed in triplicate. ${ }^{\mathrm{h}}$ APN activity, from pig kidney, was measured using Ala-p.NA as substrate. ${ }^{\mathrm{c}}$ Compounds 5 and $\mathbf{6}$ are a mixture of four stereoisomers.
}

In a third step, compounds 7 to 12 containing a $C$ terminal phenylalanine in $P_{2}^{\prime}$ position were tested and in each case the mixture of two stereoisomers $(A+B)$ showed nanomolar inhibitory potencies. A direct comparaison between 5 and 8 or 6 and 11 indicated that the 100 fold increased activities observed with 8 and 11 was due to the $S_{2}{ }^{\prime}$ subsite occupancy. Two other results could also be underlined : i) there is no direct relationship between the inhibitory potency of the $\alpha$-aminophosphinic acids reported in table 1 and those of the phosphinic peptides reported in Table 2. For instance, compound 7, which contain a methyl group in position $R_{1}$, is one of the most active inhibitor, while the corresponding $\alpha$-aminophosphinic acid is the less efficient of the series with a $\mathrm{Ki}$ value of $8 \times 10^{-6} \mathrm{M}$. The inverse situation occurs with the methionine side 
chain ; ii) For all the compounds tested, the mixture of isomers $(A+B)$ is significantly more active than $(C+D)$, showing a very large importance of the absolute configuration of the asymmetric carbons. Consequently to isolate the most potent isomers, a complete separation was performed for compounds 7 and 11. The recristallization of the $(+) \alpha$-methylbenzylamine salts of the $\alpha$-aminophosphinic acid $1 \mathrm{a}\left(\mathrm{R}=\mathrm{CH}_{3}\right)$ and $1 \mathrm{e}\left(\mathrm{R}=\mathrm{CH}_{2} \mathrm{Ph}\right)$ led to the $\mathrm{R}$ isomers ${ }^{32}$. Following the synthetic pathway reported in Figure 1, these pure isomers led in fine to the formation of compounds 7 and 11 as a mixture of isomers B and D which differed only by the absolute configuration of the second asymmetric carbon. Isomers $\mathrm{B}$ and $\mathrm{D}$ were easily separated by preparative HPLC. The isomers 7B and 11B were the most active (Table 3 ) and their stereochemical assignment (R,S,S) were determined by ${ }^{1} \mathrm{H}$ NMR spectrocopy ${ }^{33}$.

Table 3. Inhibitory potencies of optically pur phosphinic derivatives for APN, APA and APB.

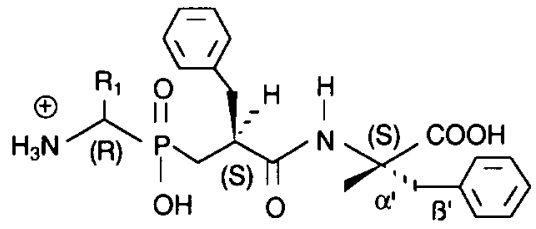

\begin{tabular}{l}
\hline \\
\cline { 3 - 4 } \\
\cline { 3 - 4 }
\end{tabular}

To determine the selectivity of these inhibitors towards the targetted enzyme, they have been tested on other $\mathrm{Zn}^{2+}$ metallopeptidases of the same family. Selectivity factors from 200 to 10,000 were obtained versus APA and higher than 10,000 versus APB (Table 3). These results are consistent with the preference of these latter enzymes for acidic or basic residues in position $S_{1}$ respectively. The best inhibitors have also been tested on two endopeptidases NEP and ACE. Indeed, accounting for the hydrophobic character of their active sites, the synthesized phosphinic compounds could inhibit efficiently these physiological enzymes. However, selectivity factors from 100 to 10,000 were obtained, showing that either the presence of the free amino group of $\mathbf{7 B}$ and $11 B$ is unfavourable for NEP or ACE recognition or the hydrophobic side chains of the inhibitors do not optimally interact with the two endopeptidases. High selectivity factors $(>100)$ were also obtained with the cytosolic leucine aminopeptidase LAP whose mechanism of action is different from that of gluzincins.

Due to their high affinity towards APN and their selectivities versus other metalloenzymes, the phosphinic inhibitors could be used for a complete charaterization of the biochemical and pharmacological 
properties of APN and the synthesis of the radiolabelled analogues of 7B is now underway in our laboratory.

In conclusion, we have developed a new series of potent and selective APN inhibitors, designed as transition state analogues interacting with the $S_{1}, S_{1}{ }^{\prime}$ and $S_{2}{ }^{\prime}$ subsites of the enzyme. This approach has led to the most potent inhibitors on APN reported to date, with Ki values in nanomolar range. Moreover these compounds could be modified to generate new dual inhibitors of neutral endopeptidase NEP and APN ${ }^{34}$, because the critical point in designing dual inhibitors is to optimize the recognition of APN.

Acknowledgements. We thank Dr. C. Llorens-Cortes for experiments with APA, Dr. S. Cadel for experiments with APB and E. Ruffet for experiments with APN. We gratefully acknowledge C. Dupuis for expert drafting of the manuscript.

\section{REFERENCES \& NOTES}

1. Maroux, S. ; Louvard, D ; Barrati, J. Biochem. Biophys. Acta 1973; 321, 282-295.

2. Zini, S. ; Fournié-Zaluski, M. C. ; Chauvel, E. ; Roques, B. P. ; Corvol, P. ; Llorens-Cortes, C. Proc. Natl. Acad. Sci. U.S.A. 1996; 93, 11968-11973.

3. Montiel, J. L. ; Cornille, F. ; Roques, B. P. ; Noble F. J. Neurochem. 1997; 68, 354-361.

4. Roques, B. P. ; Noble, F. ; Daugé, V. ; Fournié-Zaluski, M. C. ; Beaumont, A. Pharmacol. Rev. 1993; 45, 87-146.

5. Look, A. T. ; Ashmun, R. A. ; Shapiro, L. H. ; Peiper, S. C. J. Clin. Invest. 1989; 83, 1299-1307.

6. Delmas, B. ; Gelfi, J. ; L'Haridon, R. ; Vogel, L.K. ; Sjöström, H. ; Norén, O. ; Laude, H. Nature 1992; 357, 417-420.

7. Yeager, C. L. ; Ashmun, R.A. ; Williams, R. K. ; Cardellichio, C. B. ; Shapiro, L. H. ; Look, A. T. ; Holmes, K. V. Naure 1992; 357, 420-422.

8. Saiki, I. ; Fujii, H. ; Yoneda, J. ; Abe, F. ; Nakajima, M. ; Tsuruo, T. ; Azuma, I. Int. J. Cancer 1993; 54, 137-143.

9. Menrad, A. ; Speicher, D. ; Wacker J. ; Herlyn, M. Cancer Res. 1993; 53, 1450-1455.

10. Wetterholm, A. ; Medina, J. F. ; Radmark, O. ; Shapiro, R. ; Haeggström, J. ; Vallee, B. L. ; Samuelesson, B. Proc. Natl. Acad. Sci. U.S.A. 1992; 89, 9141-9145.

11. Wang, J. ; Cooper, M. Proc. Natl. Acad. Sci. U.S.A. 1993; 90, 1222-1226.

12. Vazeux, G. ; Wang, J. ; Corvol, P. ; Llorens-Cortès, C. J. Biol. Chem. 1996; 27I, 9069-9074.

13. Matthews, B. W. Acc. Chem. Res. 1988, 21, 333-340.

14. Umezawa, H. ; Aoyagi, T. ; Suda, H. ; Hamada, M. ; Takeuchi, T. J. Antibiot. 1976; 29, 97-99.

15. Aoyagi, T. ; Tobe, H. ; Kojima, F. ; Hamada, M. ; Takeuchi, T. ; Umezawa, H. J. Antibiot. 1978; 31, 636-638.

16. Chung, M. C. ; Chun, H. K ; Han, K. H. ; Lee, H. J. ; Lee, C. H. ; Kho, Y. H. J. Antibiot. 1996; 49, 99-102.

17. Umezawa, H. ; Aoyagi, T. ; Tanaka, T. ; Suda, H. ; Okuyama A. ; Naganawa, H. ; Hamada, M. ; Takeuchi, T. J. Antibiot. $1985 ; 38,1629-1630$.

18. Baker, J. O. ; Wilker, S.H. ; Bayliss, M. E. ; Prescott, J. M. Biochem. J. 1983; 22, 2089-2103.

19. Fournié-Zaluski, M. C. ; Coric, P. ; Turcaud, S. ; Bruetschy, L. ; Lucas, E. ; Noble, F. ; Roques, B. P. J. Med. Chem. 1992; 35, 1259-1266.

20. Shenvi, A. B. Biochemistry 1986; 25, 1286-1291.

21. Lejczak, B. ; Kafarski, P. ; Zygmunt, J. Biochemistry 1989; 28, 3549-3555.

22. Andersson, L. ; Isley, T. C. ; Wolfenden, R. Biochemistry 1982; $21,4177-4180$.

23. Ocain, T. D. ; Rich, D. H. J. Med. Chem. 1988; 3I, 2193-2199.

24. Gordon, E. M. ; Godgrey, J.D. ; Delaney, N. G. ; Asaad, M. M. ; Von Langen, D. ; Cushman, D. W. J. Med. Chem. 1988; $31,2199-2211$.

25. Harbeson, S. L. ; Rich, D. H. J. Med. Chem. 1989; 32, 1378-1392.

26. Bouboutou, R. ; Waksman, G. ; Devin, J. ; Fournié-Zaluski, M. C. ; Roques, B. P. Life Sci. 1984; 35, 1023-1030.

27. Schalk, C. ; d'Orchymont, H. ; Jauch, M. F. ; Tarnus, C. Arch. Biochem. Biophy. 1994; 311, 42-46.

28. Miyachi, H. ; Kato, M. ; Kato, F. ; Hashimoto, Y. J. Med. Chem. 1998; 4I, 263-265.

29. Schechter, I. ; Berger, A. Biochem. Biophys. Res. Commun. 1967; 157-162.

30. Caldwell, C.G. ; Sahoo, S.P. ; Polo, S.A. ; Eversole, R.R. ; Lanza, T.J. ; Mills, S.G. ; Niedzwiecki, L.M. ; IzquierdoMartin, M. ; Chang, B.C. ; Harrison, R.K. ; Kuo, D.W. ; Lin, T.Y. ; Stein, R.L. ; Durette, P.L. ; Hagmann, W.K. Bioorg. Med. Chem. Lett. 1996, 6(3), 323-328.

31. Xie, J. ; Soleilhac, J. M. ; Schmidt, C. ; Peyroux, J. ; Roques, B. P ; Fournié-Zaluski, M. C. J. Med. Chem. 1989; $32,1497$. 1503.

32. Baylis, E. K. ; Campbell, C. D. ; Dingwall, J. G. J. Chem. Soc. 1984; 2845-2853.

33. Fournié-Zaluski, M. C. ; Lucas-Soroca, E. ; Devin, J. ; Roques, B. P. J. Med. Chem. 1986; 29, $751-757$.

34. Chen, H. ; Noble, F. ; Coric, P. ; Fournié-Zaluski, M.C. ; Roques, B.P. Proc. Natl. Acad. Sci. USA 1998; 95, 12028-12033. 